\title{
ALGORITMA VAN AARDENNE-EHRENFEST DAN DE BRUIJN DALAM MENCARI SIRKUIT EULER PADA GRAF BERARAH UNTUK MEREKONSTRUKSI RANTAI RNA DARI G-FRAGMENTS DAN $(U, C)$-FRAGMENTS
}

\author{
D. Ismayasari ${ }^{1}$, I W. Sudarsana ${ }^{2}$ dan I N. Suwastika ${ }^{3}$ \\ 1,2 Program Studi Matematika Jurusan Matematika FMIPA Universitas Tadulako \\ 3 Program Studi Biologi Jurusan Biologi FMIPA Universitas Tadulako \\ Jalan Soekarno-Hatta Km. 09 Tondo, Palu 94118, Indonesia \\ 1ditaismaya@gmail.com, 2sudarsanaiwayan@yahoo.co.id, 3isuwastika@yahoo.com.au
}

\begin{abstract}
$R N A$ chains defined as the sequence of the letters taken from the set $\sum=\{\mathrm{A}, \mathrm{G}, \mathrm{U}, \mathrm{C}\}$ where $\mathrm{A}, \mathrm{G}, \mathrm{U}$ and $\mathrm{C}$ represent of Adenine, Guanine, Uracil and Cytosine respectively. Formally RNA chains can be found fragmented by Gfragments and $(U, C)$-fragments and it is difficult to reconstruction in the original form. Infact, we need $R N A$ chains in the original form even it is frequenly found in fragmented form. Reconstruction of $R N A$ chains fragmented by $G-$ fragments and $(U, C)$-fragments can be used circuit Euler on directed graph. In that directed graph, we can find the circuit Euler by using van Aardenne-Ehrenfest and de Bruijn algorithms. In this research, we discussed reconstruction of RNA Human Herpesvirus 5 in fragmented fromby finding circuit Euler in the directed graph using van Aardenne-Ehrenfest and de Bruijn algorithms. The results show that the RNA Human Herpesvirus 5 in the original form (base on $\mathrm{NCBI}$ ) can be reconstructed by finding circuit Euler in the directed graph using van AardenneEhrenfest and de Bruijn algorithms.
\end{abstract}

Keywords : Van Aardenne-Ehrenfest and de Bruijn algorithm, Euler Circuit, Directed Graph, Reconstruct of RNA Chains fragmented by $G$-fragments and $(U, C)$-fragments .

\section{ABSTRAK}

Rantai $R N A$ didefinisikan sebagai barisan dari simbol-simbol huruf yang diambil dari himpunan $\sum=\{\mathrm{A}, \mathrm{G}, \mathrm{U}, \mathrm{C}\}$ dimana A merepresentasikan adenin, G merepresentasikan guanin, $U$ merepresentasikan urasil dan C merepresentasikan sitosin. Rantai RNA dapat terputus karena dipengaruhi dua jenis enzim yaitu G-enzyme dan $(U, C)$-enzyme sehingga menjadi fragmen-fragmen yaitu $G$-fragments dan $(U, C)$-fragments. Rantai $R N A$ yang telah menjadi G-fragments dan $(U, C)$-fragments dapat direkonstruksi kembali menjadi barisan rantai $R N A$ asli. Merekonstruksi rantai $R N A$ yang terfragmen dapat digunakan graf berarah yaitu dengan menghubungkan fragmenfragmen ke titik-titik dan sisi-sisi berarah sehingga terbentuk graf berarah RNA. Kemudian dapat dilakukan pencarian sirkuit Euler pada graf berarah $R N A$ tersebut sehingga fragmen-fragmen dapat digabungkan kembali menjadi rantai $R N A$ asli. Algoritma van Aardenne-Ehrenfest dan de Bruijn adalah algoritma pencarian sirkuit Euler pada graf berarah. Pada penelitian ini akan dibahas mengenai merekonstruksi rantai $R N A$ dari G-fragments dan $(U, C)$-fragments dengan menggunakan algoritma van Aardenne-Ehrenfest dan de Bruijn dalam mencari sirkuit Euler pada graf berarah. Sebagai studi kasus, data rantai $R N A$ asli yang digunakan dalam penelitian ini diunduh dari basis data NCBI untuk satu organisme yaitu Human Herpesvirus 5. Hasil yang diperoleh rantai RNAasli dapat direkonstruksi kembali menggunakan sirkuit Euler yang didapat dari algoritma van Aardenne-Ehrenfest dan de 
Bruijn menjadi rantai $R N A$ asli sesuai dengan data dari NCBI walaupun rantai RNA Human Herpesvirus 5 telah terfragmen menjadi G-fragments dan (U,C)-fragments.

Kata kunci : Algoritma van Aardenne-Ehrenfest dan de Bruijn, Sirkuit Euler, Graf Berarah, Rekonstruksi Rantai RNA dari G-fragments dan $(U, C)$-fragments.

\section{PENDAHULUAN}

\subsection{Latar Belakang}

$R N A$ atau asam ribonukleat yaitu senyawa yang merupakan bahan genetik dan memainkan peran utama dalam ekspresi genetik. $R N A$ memiliki bentuk rantai tunggaldantidak berpilin. Basa nitrogen RNA juga dibedakan menjadi basa purin dan basa pirimidin. Basa purinnya tersusun atas adenin (A) dan guanin (G), sedangkan basa pirimidinnya tersusun atas $\operatorname{sitosin}(\mathrm{C})$ dan urasil $(\mathrm{U})$. Terbentuknya rantai $R N A$ dipengaruhi oleh dua jenis enzim yang memutus ikatan antara asam -asam pembentuk rantai $R N A$. Kedua enzim tersebutadalah $G$ enzyme dan $(U, C)$-enzyme. $G$-enzyme memutus rantai $R N A$ setiap setelah mata rantai $G$ menjadi $G$-fragments, sedangkan (U,C)-enzyme memutus rantai $R N A$ setiap setelah mata rantai $U$ atau $C$ menjadi $(U, C)$-fragments. Kedua proses tersebut disebut proses fragmentasi (Noorzaman, 2007).

Pada $G$-fragments dan (U,C)-fragments terdapat satu fragmen abnormal yaitu jika $G$ fragment tidak diakhiri dengan mata rantai $G$ dan (U,C)-fragments tidak diakhiri dengan mata rantai $U$ atau C. Jika $G$-fragments dan (U,C)-fragments diakhiri dengan mata rantai A maka akan terdapat dua fragmen yang abnormal, serta dari dua fragmen abnormal tersebut fragmen abnormal terpanjang yang harus dipilih untuk melakukan rekonstruksi rantai $R N A$. Dari $G-$ fragments dan (U,C)-fragmentsterdapat pula subfragmen yang merupakan sebuah subrantai tidak kosong dihasilkan apabila sebuah $G$-fragment dipecah kembali oleh (U,C)-enzyme ataupun sebaliknya jika sebuah (U,C)-fragment dipecah kembali oleh G-enzyme. Subfragmen yang dihasilkan oleh hasil pemecahan kembali oleh enzim tersebut disebut extended bases sedangkan prosesnya disebut subfragmentasi. Sebuah fragmen harus terpisah paling sedikit kedalam tiga extended bases sebelum dapat ditentukan subfragmen-subfragmen yang termasuk ke dalam interior extended base. Jika sebuah fragmen mengandung subfragmen tunggal, yang berarti setelah terjadi pemecahan hanya didapatkan subragmen berupafragmen awal, maka fragmen ini disebut unsplittable fragments (Noorzaman, 2007).

Teori graf dapat digunakan dalam merekonstruksi rantai $R N A$. Yaitu dengan menghubungkan sebuah graf dengan sembarang daftar lengkap dari G-fragments dan (U,C)fragments. Titik pada graf dapat merepresentasikan fragmen dan sisi pada graf dapat merepresentasikan hubungan sepasang fragmen yang terurut. Urutan fragmen dalam rantai $R N A$ ditunjukkan oleh arah anak panah pada graf. Graf yang mempunyai arah disebut dengan graf berarah. Dengan demikian dalam merekonstruksi rantai $R N A$ digunakan grafterhubung 
berarah. Selanjutnya dengan mencari sirkuit Euler pada graf berarah maka fragmen-fragmen dari G-enzyme dan (U,C)-enzyme dapat digabungkan, sehingga terbentuk rantai $R N A$ baru yang sesuai dengan rantai aslinya. Untuk pencarian sirkuit Euler pada graf berarah bisa dilakukan dengan menggunakan algoritma van Aardenne-Ehrenfest dan de Bruijn (Eiselt, et al., 1995). Dimana grafberarah merupakan keadaan khusus dari suatu graf, yaitu sisi-sisinya memiliki arah, sehingga ada perlakuan khusus dalam mencari sirkuit Eulernya, yaitu harus memperhatikan arah dari setiap sisi dalam graf berarah.

\subsection{Rumusan Masalah}

Berdasarkan latar belakang di atas, maka permasalahan yang akan dikaji dalam penelitian ini yaitu bagaimana merekonstruksi rantai $R N A$ dari G-fragments dan $(U, C)$ fragments dengan menggunakan algoritma van Aardenne-Ehrenfest dan de Bruijn dalam mencari sirkuit Euler pada graf berarah. Sebagai ilustrasi kasus, berikut merupakan contoh sederhana dalam merekonstruksi rantai $R N A$ dari G-fragments dan (U, C)-fragments:

Contoh: Potongan rantai RNA asli Human Herpesvirus 5 yaitu "AUGCUGUCG", misalkan ditemukan fragmentasi dari rantai $R N A$ tersebut sebagai berikut:

- $G$-fragments $=\{C \cup G, \cup C G, A \cup G\}$ dan $(U, C)$-fragments $=\{G C, \cup, G \cup, C, G, A U\}$

- $G$-fragments dan (U,C)-fragments terpecah kembali atau tersubfragmentasi, yaitu:

G-fragments (disubfragmentasi dengan (U,C)-enzyme) $=\{\{\mathrm{C}-\mathrm{U}-\mathrm{G}\},\{\mathrm{U}-\mathrm{C}-\mathrm{G}\},\{\mathrm{AU}-\mathrm{G}\}\}$ $(U, C)$-fragments (disubfragmentasi dengan $G$-enzyme) $=\{\{\mathrm{G}-\mathrm{C}\},\{\mathrm{U}\},\{\mathrm{G}-\mathrm{U}\},\{\mathrm{C}\},\{\mathrm{G}\}$, $\{\mathrm{AU}\}\}$

- Menentukan fragmen awal dan akhir dari rantai $R N A$ :

Fragmen Abnormal $=\{\mathrm{G}\}$, Interiorextended bases $=\{\{\mathrm{U}\},\{\mathrm{C}\}\}$, Unsplittable fragments $=$ $\{\{U\},\{C\},\{G\},\{A \cup\}\}$. Lihat pada unsplittable fragments, fragmen $\{\{U\},\{U\}\}$ merupakan interior extended bases dan fragmen $\{G\}$ merupakan fragmen abnormal (akhir rantai $R N A$ ), sehingga fragmen $\{A U\}$ secara otomatis menjadi awal dari rantai $R N A$.

- Membangun graf berarah yaitu identifikasi semua fragmen normal yang memiliki lebih dari satu extended bases. Gunakan extended bases pertama dan terakhir sebagai titik dan tarik sisi berarah dari extended bases pertama ke extended basesterakhir. Dimulai dari extended bases awal rantai $R N A$ dan labeli sisi berarah sesuai fragmen serta labeli titik sesuai extended bases pertama dan terakhir. Serta identifikasi fragmen abnormal yang terpanjang, kemudian tarik sisi berarah dari extended bases fragmen abnormalke extended bases pertama (awal) dalam rantai $R N A$. Serta labeli sebagai $X^{*} Y$ dimana $X$ adalah fragmen abnormal yang terpanjang dan $Y$ adalah extended bases pertama dari rantai $R N A$. Gambar 1:

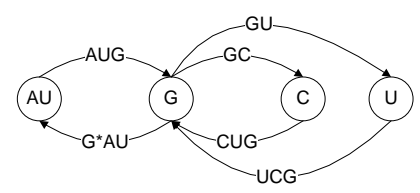

Gambar 1 : Graf Berarah RNA 
Mencari sirkuit Euler dari Gambar 1 yaitu menuliskan tiap label pada sisi berarah yang dilalui dengan memperhatikan tumpang tindih antara fragmen-fragmen pada sisi berarah tersebut. Fragmen yang saling tumpang tindih dituliskan satu kali. Dimulai dari titik yang berlabel extended base awal rantai dan diakhiri pada label sisi berarah fragmen abnormal, sirkuit Euler yaitu :

$$
\text { AUG - GC - CUG - GU - UCG - G*AU }
$$

Dengan demikian diperoleh rantai RNA yaitu AUGCUGUCG yang sama dengan potongan rantai RNA asli Human Herpesvirus 5.

\subsection{Tujuan Penelitian}

Berdasarkan permasalahan di atas, maka tujuan yang akan dicapai dalam penelitianini yaitu merekonstruksi rantai $R N A$ dari $G$-fragments dan (U,C)-fragments dengan menggunakan algoritma van Aardenne-Ehrenfest dan de Bruijn dalam mencari sirkuit Euler pada graf berarah sehingga memperoleh urutan susunan barisan rantai $R N A$ yang sama dengan rantai $R N A$ asli.

\subsection{Batasan Masalah}

Penelitian ini terbatas pada data barisan rantai $R N A$ asli yang akan dilakukan proses rekonstruksi merupakan data yang diunduh pada basis data National Centerfor Biotechnology Information (NCBI) dan dipilih satu organisme yaitu Human Herpesvirus 5.

\section{METODE PENELITIAN}

Penelitian dilakukan sesuai dengan prosedur dibawah ini :

1. Memulai penelitian.

2. Studi literatur.

3. Rantai RNA asli.

4. Fragmentasi rantai RNA (G-Fragments dan (U,C)-Fragments); Subfragmentasi; Extended Base; Fragmen Abnormal, Interior Extended Base, Unsplittable fragment.

5. Gambar graf berarah yang dibangun dari Fragmentasi dan Subfragmentasi rantai $R N A$.

6. Pada graf berarah cari sirkuit Euler menggunakan Algoritma van Aardenne - Ehrenfest dan de Bruijn.

7. Susunan rantai $R N A$.

8. Melihat apakah rantai $R N A$ yang direkonstruksi merupakan rantai $R N A$ asli. Jika rantai $R N A$ merupakan rantai $R N A$ asli maka dilanjutkan kelangkah selanjutnya, namun jika tidak maka kembali ke langkah (3).

9. Menyimpulkan hasil penelitian.

10. Selesai. 


\section{HASIL DAN PEMBAHASAN}

\subsection{Dekripsi Data Rantai RNA Asli}

Penelitian ini menggunakan satu organisme yang diunduh pada basis data NCBI yaitu organisme Human Herpesvirus 5. Organisme tersebut memiliki urutan rantai RNA asli yang panjang, oleh karena itu dalam melakukan serangkaian proses merekonstruksi rantai $R N A$ dari $G$-fragments dan (U,C)-fragments sehingga memperoleh urutan rantai $R N A$ asli akan mengalami kesulitan dikarenakan data yang panjang. Untuk mempermudah penelitianinimaka rantai $R N A$ tersebut akan dipotong secara manual menjadi urutan rantai $R N A$ yang relatif lebih pendek. Dalam hal ini peneliti menggunakan software BioEdit untuk membantu dalam hal pemotongan rantai $R N A$ secara manual agar tidak terjadi kesalahan dalam memotong rantai $R N A$ yaitu harus mengikuti urutan-urutan kodon atau asam-asam amino polipeptida atau protein yang telah diperoleh.

\subsection{Penggunaan Algoritma van Aardenne-Ehrenfest dan de Bruijn dalam Mencari Sirkuit Euler pada GrafBerarah untuk Merekonstruksi Rantai RNAdari G-fragments dan ( $U$, C)-fragments}

Jika ada G-fragments yaitu $H=\left\{G_{1}, \ldots G_{k}\right\}$ dan $(U, C)$-fragments yaitu $J=\left\{F_{1}, \ldots F_{i}\right\}$ maka terdapat $G_{1, s}$ yang merupakan subfragmen extended base terakhir dari $G_{1}$ yang bertetangga atau saling tumpang tindih dengan subfragmen extended base pertama dari $\mathrm{F}_{\mathrm{i}}$ yaitu $F_{i, 1}$. Dalam hal ini subfragmen tersebut adalah $\sum=\left\{\mathrm{G}, \mathrm{AG}, \mathrm{AAG}, \mathrm{A}^{3} \mathrm{G}, \mathrm{A}^{4} \mathrm{G}, \mathrm{A}^{\mathrm{N}} \mathrm{G}\right\}$ dengan $N \geq 1$. Begitupun sebaliknya, terdapat $F_{1, s}$ yang merupakan subfragmen extended base terakhir dari $\mathrm{F}_{1}$ yang bertetangga atau saling tumpang tindih dengan subfragmen extended base pertama dari $G_{k}$ yaitu $G_{k, 1}$. Dalam hal ini subfragmen tersebut adalah $\sum=$ $\left\{U, C, A U, A A U, A^{3} U, A^{4} U, A^{N} U, A C, A A C, A^{3} C, A^{4} C, A^{N} C\right\}$ dengan $N \geq 1$.

Algoritma van Aardenne-Ehrenfest dan de Bruijn adalah algoritma pencarian sirkuit Euler pada graf berarah. Dalam mencari sirkuit Euler pada graf berarah, pertama-tama algoritma ini akan membentuk spanning arborescence yang berakar disatu titik, setelah itu sisisisi berarah yang keluar dari tiap-tiap titik dilabeli secara terurut dengan label terbesar atau terakhir adalah sisi berarah pada spanning arborescence, terakhir mencari sirkuit Euler mengikuti pelabelan sisi-sisi berarah tersebut mulai dari label terkecil.

Dalam merekonstruksi rantai $R N A$ yang panjang maka graf berarah yang diperolehakan memiliki banyak titik dan banyak sisi-sisi berarah dimana sisi-sisi berarah merepresentasikan fragmen-fragmen penyusun rantai $R N A$. Algoritma ini akan kesulitan dalam membentuk suatu spanning arborescence dan juga sulit untuk memberi label yang terurut pada sisi-sisi berarah dari graf berarah $R N A$ yang terbentuk. Yang dimana spanning arborescence dan label sisi berarah haruslah berkorespondensi dengan suatu rantai $R N A$ asli. Berikut beberapa simulasi 
yang dilakukan untuk melihat keefektifan penggunaan algoritma van Aardenne-Ehrenfest dan de Bruijn.

Kasus 3.1. Rantai $R N A$ yang akan direkonstruksi panjangnya adalah 11 yaitu "UGAAGCCCAGC":

- G-fragments = \{AAG, CCCAG, UG, C $\}$ dan $(U, C)$-fragments = $\{$ GAAGC, C, U, C, AGC $\}$

- G-fragments (disubfragmentasi dengan $(U, C)$-enzyme) $=\{\{A A G\},\{C-C-C-A G\},\{U-G\},\{C\}\}$ - (U,C)-fragments (disubfragmentasi dengan $G$-enzyme) $=\{\{G-A A G-C\},\{C\},\{U\},\{C\},\{A G-C\}\}$

- Fragmen Abnormal $=\{C\}$

- Interior extended bases $=\{\{\mathrm{C}\},\{\mathrm{C}\},\{\mathrm{AAG}\}\}$

- Unsplittable fragmen $=\{\{A A G\},\{C\},\{C\},\{U\},\{C\}\}$. Diketahui $\{U\}$ merupakan awal rantai $R N A$.

- Graf berarah

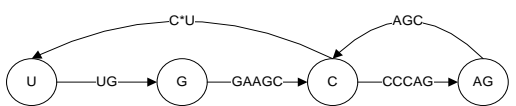

Gambar 2 : Graf Berarah RNA Kasus 3.1

- $\quad$ Pencarian sirkuit Euler (algoritma van Aardenne-Ehrenfest dan de Bruijn) :

Spanning arborescence yang berakar di titik G, yaitu :

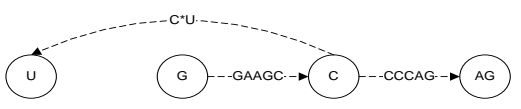

Gambar 3 : Spanning Arborescence untuk graf berarah RNA Gambar 2

Melabeli sisi-sisi berarah yang keluar dari titik-titik pada Gambar 2, yaitu :

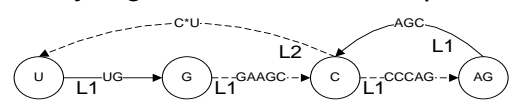

Gambar 4 : Pelabelan pada sisi berarah untuk graf berarah RNA Gambar 2

Mencari sirkuit Euler, yaitu dari Gambar 3 dapat dilihat sirkuit Euler yang terbentuk diawali dari titik yang merupakan fragmen awal dengan memperhatikan tumpang tindih antar fragmen, yaitu :

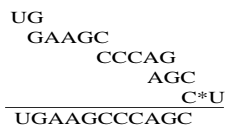

Gambar 5 : Hasil Rekonstuksi Rantai RNA Kasus 3.1

Dari Gambar 5 hasil rekonstruksi rantai $R N A$ diperoleh rantai yang sama dengan rantai aslinya yaitu UGAAGCCCAGC. Perhatikan graf berarah $R N A$ pada Gambar 1 pada tiap titik-titiknya hanya terhubung oleh 1 sisi berarah dengan banyaknya titik-titik sama dengan 4 .

Kasus 3.2. Rantai $R N A$ yang akan direkonstruksi panjangnya adalah 15 yaitu "CCCAGCGACUUGCGG", sehingga - G-fragments $=\{$ ACUUG, CCCAG, CG, CG G $\}$ dan $(U, C)$-fragments $=\{\mathrm{GAC}, \mathrm{U}, \mathrm{U}, \mathrm{GC}, \mathrm{GG}, \mathrm{C}, \mathrm{C}, \mathrm{C}, \mathrm{AGC}\}$
- G-fragments (disubfragmentasi dengan $(U, C)$-enzyme) $=\{\{\mathrm{AC}-\mathrm{U}-\mathrm{U}-\mathrm{G}\},\{\mathrm{C}-\mathrm{C}-\mathrm{C}-\mathrm{AG}\},\{\mathrm{C}-\mathrm{G}\},\{\mathrm{C}-\mathrm{G}\},\{\mathrm{G}\}\}$ - (U,C)-fragments (disubfragmentasi dengan $G$-enzyme) $=\{\{G-A C\},\{U\},\{U\},\{G-C\},\{G-G\},\{C\},\{C\},\{C\},\{A G-C\}\}$ - Fragmen Abnormal $=\{\mathrm{GG}\}$

- Interior extended bases $=\{\{\mathrm{U}\},\{\mathrm{U}\},\{\mathrm{C}\},\{\mathrm{C}\}\}$

- Unsplittable fragmen $=\{\{\mathrm{G}\},\{\mathrm{U}\},\{\mathrm{U}\},\{\mathrm{C}\},\{\mathrm{C}\},\{\mathrm{C}\}$. Diketahui $\{\mathrm{C}\}$ merupakan awal rantai $R N A$ 
- Graf berarah :

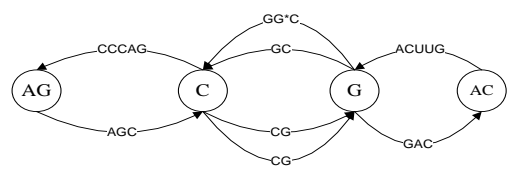

Gambar 6 : Graf Berarah RNA Kasus 3.2

- Pencarian sirkuit Euler (algoritma van Aardenne-Ehrenfest dan de Bruijn) :

Pertam a, spanning arborescence (1) dari Gambar 5 berakar dititik G:

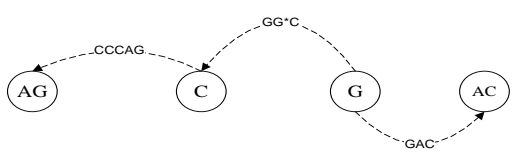

Gambar 7 : Spanning Arborescence (1) untuk graf berarah RNA Gambar 6 Melabeli sisi-sisi berarah (1) yang keluar dari titik-titik pada Gambar 6:

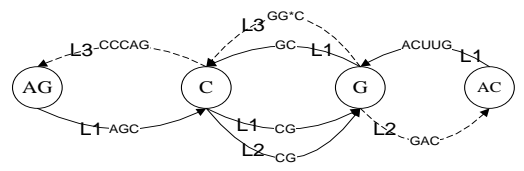

Gambar 8 : Pelabelan pada sisi berarah (1) untuk graf berarah RNA Gambar 6 Mencari sirkuit Euler, yaitu dari Gambar 8 dapat dilihat ternyata dengan pemilihan titik G sebagai akar arborescence mengakibatkan tidak adanya sirkuit Euler pada graf berarah $R N A$. Oleh karena itu akan kembali dibangun spanning arborescence, yaitu:

Kedua, spanning arborescence (2) masih berakar dititik AC, yaitu:

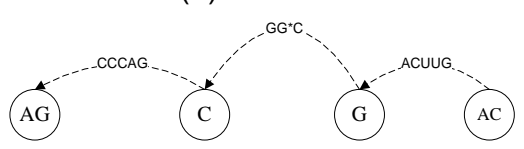

Gambar 9 : Spanning Arborescence (2) untuk graf berarah RNA Gambar 6

Melabeli sisi-sisi berarah (2) yang keluar dari titik-titik pada Gambar 6, yaitu :

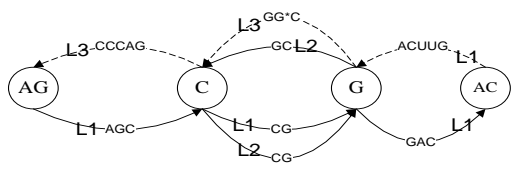

Gambar 10 : Pelabelan pada sisi berarah (2) untuk graf berarah RNA Gambar 6

Mencari sirkuit Euler, yaitu dari Gambar 10 dapat dilihat ternyata dengan pemilihan titik AC sebagai akar arborescence mengakibatkan tidak adanya sirkuit Euler pada graf berarah $R N A$. Oleh karena itu akan kembali dibangun spanning arborescence, yaitu: 
Ketiga, spanning arborescence (3) yang akan dibangun berakar dititik AG, yaitu :

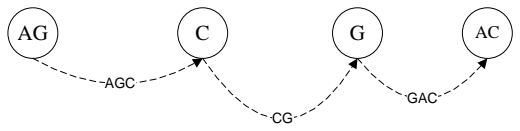

Gambar 11 : Spanning Arborescence (3) untuk graf berarah RNA Gambar 6 Melabeli sisi-sisi berarah (3) yang keluar dari titik-titik pada graf Gambar 6, yaitu :

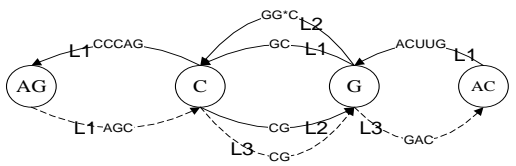

Gambar 12 : Pelabelan pada sisi berarah (3) untuk graf berarah RNA Gambar 6 Mencari sirkuit Euler, yaitu dari Gambar 12 dapat dilihat ternyata dengan pemilihan titik AG sebagai akar arborescence mengakibatkan tidak adanya sirkuit Euler pada graf berarah $R N A$.

Setelah pembentukkan spanning arborescence yang ke-3 ini tidak terdapat lagi pilihan spanning arborescence yang dapat dibangun dari graf berarah Gambar 6. Yang berarti algoritma van Aardenne-Ehrenfest dan de Bruijn tidak dapatmenemukan rantai $R N A$ asli dari kasus 3.2 ini. Hal ini terjadi karena antara spanning arborescence yang dibangun serta memberi label secara terurut pada sisi-sisi berarah yang merepresentasikan fragmen-fragmen tidak berkorespondensi dengan urutan fragmen-fragmen dari rantai $R N A$ asli. Perhatikanpada rantai $R N A$ asli yang diketahui, G-fragmentCCCAG merupakan urutan yang petama dari rantai RNA asli. Saat membangun spanning aborescence (1) pada Gambar 7 yang berakar di titik G, fragmen CCCAG menjadi sisi berarah pada spanning aborescence (1) karena fragmentersebut menghubungkan titik $C$ ke titik $A G$ yang pastinya pada tahap memberi label sisi berarah tersebut akan dilabeli dengan pelabelan terbesar pada Gambar 8. Selanjutnya pada saat membangun spanning aborescence (2) pada Gambar 9 yang berakar di titik AC, fragmen CCCAG menjadi sisi berarah pada spanning aborescence (2) karena satu-satunya sisi berarah yang menghubungkan titik $C$ ke titik $A G$ yang pastinya pada tahap memberi label sisi berarah tersebut akan dilabeli dengan pelabelan terbesar pada Gambar 10. Kemudian pada saat membangun spanning aborescence (3) pada Gambar 11 yang berakar di titik AG, masalah terpecahkan. Fragmen CCCAG tidak menjadi sisi berarah pada spanning aborescence (3)dan sisi berarah tersebut dilabeli dengan pelabelan terkecil pada Gambar 12. Akan tetapi perhatikan kembali rantai $R N A$ asli yang diketahui, $(U, C)$-fragment GAC berada pada urutan pertama untuk sisi-sisi berarah yang diawali dengan titik $G$. Dengan memilih titik AG sebagai akar arborescence membuat sisi berarah GAC yang menghubungkan titik G ke titik AC menjadi sisi berarah pada spanning aborescence (3) yang pastinya pada tahap memberi label, sisi berarah tersebut akan dilabeli dengan pelabelan terbesar pada Gambar 12. Dengan demikian, dapat dikatakan algoritma van Aardenne-Ehrenfest dan de Bruijn tidak bekerja dengan efektif saat pencarian sirkuit Euler pada graf berarah RNAGambar 6. Dari kasus 3.1 dan 3.2, maka 
algoritma van Aardenne-Ehrenfest dan de Bruijn dapat bekerja dengan efektif dalam mencari sirkuit Euler pada graf berarah untuk merekonstruksi rantai $R N A$ dari $G$-fragments dan $(U, C)$ fragments sehingga memperoleh urutan rantai $R N A$ asli, yaitu :

1. Graf berarah $R N A$ yang dibangun dari $G$-fragments dan (U,C)-fragments memiliki titiktitik yang pada tiap titik-titiknya hanya dihubungkan atau terhubung oleh 1 sisi berarah.

2. Apabila graf berarah $R N A$ yang dibangun dari G-fragments dan (U,C)-fragments memiliki titik-titik yang terhubung oleh lebih dari sama dengan 2 sisi-sisi berarah maka banyaknya titik-titik yang terdapat pada graf berarah $R N A$ tersebut adalah harus sama dengan 2 atau sama dengan 3.

3. Dalam beberapa kasus, saat graf berarah $R N A$ yang dibangun dari G-fragments dan $(U, C)$-fragments memiliki banyak titik-titik yaitu lebih dari sama dengan 4 , dan juga titiktitik tersebut terhubung oleh lebih dari sama dengan 2 sisi-sisi berarah maka algoritma ini dapat bekerja efektif dan dapat pula tidak bekerja dengan efektif. Hal ini terjadi dikarenakan dari urutan susunan fragmen-fragmen rantai $R N A$ asli yang diketahui tidak saling berkorespondensi dengan spanning arborescence yang dibangun dan memberi label sisi-sisi berarah pada graf berarah $R N A$ sehingga dapat membuat algoritma ini menjadi bekerja secara efektif maupun tidak efektif.

\subsection{Penggunaan Algoritma van Aardenne-Ehrenfest dan de Bruijn dalam Mencari Sirkuit} Euler pada Graf Berarah untuk Merekonstruksi Rantai RNA dari G-fragments dan (U,C)-fragments Organisme Human Herpesvirus 5

Rantai RNA organisme Human Herpesvirus 5 memiliki panjang 237 bp. Rantai RNA tersebut akan dipotong-potong menjadi beberapa bagian rantai $R N A$ yang relatiflebih pendek. Yaitu:

\begin{tabular}{rrr}
\hline AUG CUG UCG GUG AUG GUC UCU UCC UCU CUG GUC CUG AUC GUC UUU CUU CUA GGC & GGU ACG GUU UAU UGC GAC GGU CUU UCU \\
ACG AUA AAG AAU ACA AAG CCG CAG UGU CGU CCA GAG GAU UAC GCG & GAU UAC GCG ACC AGA UUG CAA \\
CUA GGC GCU UCC GAG GAG GCG AAG CCG GCG ACG ACG ACG AUA & AAA CCU ACG UUG GUA GGU CAC GUA GGU ACG \\
CUC CGC GUC ACC UUU CAU CGA GUA AAA CCU & UUG CAA GAU CUC CGC \\
CUU UCU UUU CCG CGU GUC GGG UAG & \\
\hline
\end{tabular}

Gambar 13 : Rantai RNA dari Organisme Human Herpesvirus 5 yang telah Dipotong-potong

Potongan rantai RNA ke-1 organisme Human Herpesvirus 5 yang akan direkonstruksi panjangnya adalah 54 yaitu:

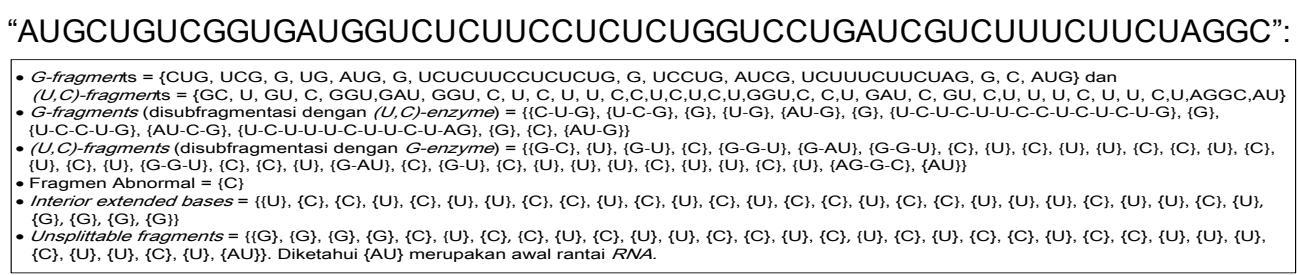


- Graf berarah :

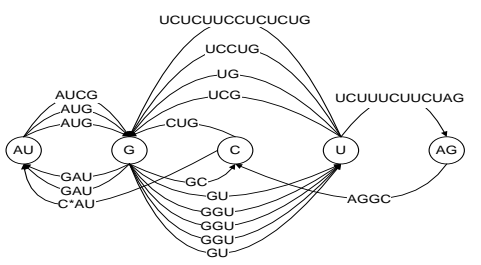

Gambar 14 : Graf Berarah RNA Ke-1 Organisme Human Herpesvirus 5

- $\quad$ Pencarian sirkuit Euler (algoritma van Aardenne-Ehrenfest dan de Bruijn) :

Spanning arborescence yang berakar di titik AG, yaitu :

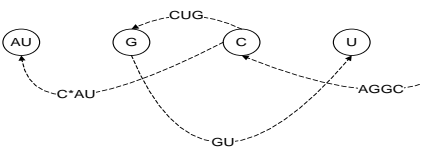

Gambar 15 : Spanning Arborescence untuk graf berarah RNA Gambar 14 Melabeli sisi-sisi berarah yang keluar dari titik-titik pada Gambar 14, yaitu :

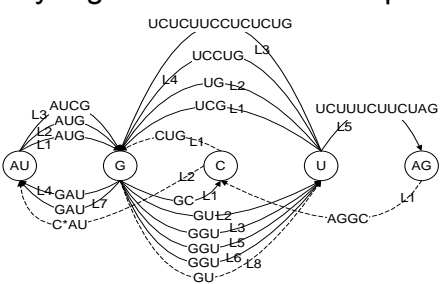

Gambar 16 : Pelabelan pada sisi berarah untuk graf berarah RNA Gambar 13 Mencari sirkuit Euler, yaitu dari Gambar 16 dapat dilihat sirkuit Euler yang terbentuk dengan memperhatikan tumpang tindih antar fragmen yaitu :

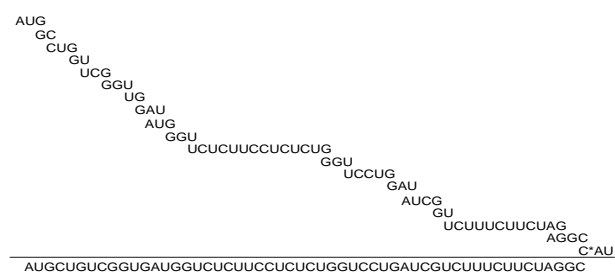

(1)

Gambar 17 : Hasil Rekonstuksi Rantai RNA Ke-1 Organisme Human Herpesvirus 5

Potongan rantai RNA ke-2 organisme Human Herpesvirus 5 yang akan direkonstruksi panjangnya adalah 45 yaitu:

"ACGAUAAAGAAUACAAAGCCGCAGUGUCGUCCAGAGGAUUACGCG":

- G-fragments = \{ AUAAAG, AAUACAAAG, CCG, CAG, UG, UCG, UCCAG, AG, G, AUUACG, CG, ACG $\}$ dan

$(U, C)$-fragments $=\{$ GAU, AAAGAAU, AC, AAAGC, C, GC, AGU, GU, C, GU, C, C, AGAGGAU, U, AC, GC, G, AC $\}$

- G-fragments (disubfragmentasi dengan $(U, C)$-enzyme) $=\{$ AU-AAAG $\},\{A A U-A C-A A A G\},\{C-C-G\},\{C-A G\},\{U-G\},\{U-C-G\},\{U-C-C-A G\},\{A G\},\{G\}$,

\{AU-U-AC-G\}, \{C-G\}, \{AC-G\}\}

- (U,C)-fragments (disubfragmentasi dengan G-enzyme) $=\{\{\mathrm{G}-\mathrm{AU}\},\{\mathrm{AAAG}-\mathrm{AAU}\},\{\mathrm{AC}\},\{\mathrm{AAAG}-\mathrm{C}\},\{\mathrm{C}\},\{\mathrm{G}-\mathrm{C}\},\{\mathrm{AG}-\mathrm{U}\},\{\mathrm{G}-\mathrm{U}\},\{\mathrm{C}\},\{\mathrm{G}-\mathrm{U}\},\{\mathrm{C}\},\{\mathrm{C}\}$,

$\{A G-A G-G-A U\},\{U\},\{A C\},\{G-C\},\{G\},\{A C\}\}$

- Fragmen Abnormal $=\{G\}$

- Interior extended bases $=\{\{\mathrm{AC}\},\{\mathrm{C}\},\{\mathrm{C}\},\{\mathrm{C}\},\{\mathrm{C}\},\{\mathrm{U}\},\{\mathrm{AC}\},\{\mathrm{AG}\},\{\mathrm{G}\}\}$

- Unsplittable fragments $=\{\{\mathrm{AG}\},\{\mathrm{G}\},\{\mathrm{AC}\},\{\mathrm{C}\},\{\mathrm{C}\},\{\mathrm{C}\},\{\mathrm{C}\},\{\mathrm{U}\},\{\mathrm{AC}\},\{\mathrm{G}\},\{\mathrm{AC}\}\}$. Diketahui $\{\mathrm{AC}\}$ merupakan awal rantai $R N A$ 
- Graf berarah :

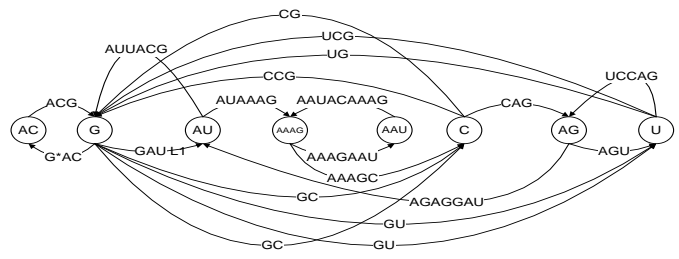

Gambar 18 : Graf Berarah RNA Ke-2 Organisme Human Herpesvirus 5

- $\quad$ Pencarian sirkuit Euler (algoritma van Aardenne-Ehrenfest dan de Bruijn) :

Spanning arborescence yang berakar di titik AAAG, yaitu :

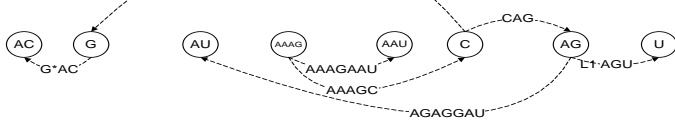

Gambar 19 : Spanning Arborescence untuk graf berarah RNA Gambar 18

Melabeli sisi-sisi berarah yang keluar dari titik-titik pada Gambar 18, yaitu :

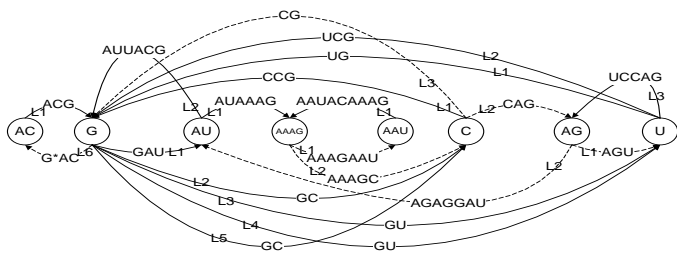

Gambar 20 : Pelabelan pada sisi berarah untuk graf berarah RNA Gambar 18

Mencari sirkuit Euler, yaitu dari Gambar 20 dapat dilihat sirkuit Euler yang terbentuk dengan memperhatikan tumpang tindih antar fragmen yaitu :

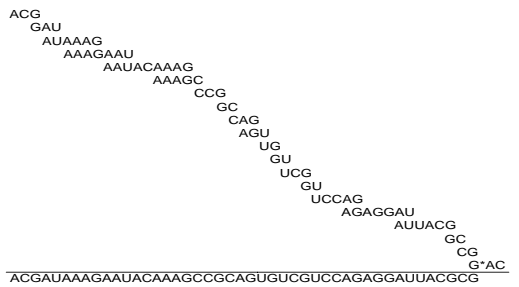

(2)

Gambar 21 : Hasil Rekonstuksi Rantai RNA Ke-2 Organisme Human Herpesvirus 5

Potongan rantai RNA ke-3 organisme Human Herpesvirus 5 yang akan direkonstruksi panjangnya adalah 42 yaitu:

"CUAGGCGCUUCCGAGGAGGCGAAGCCGGCGACGACGACGAUA":

- G-fragments = \{G, CG, CUUCCG, AG, G, AG, G, CG, AAG, CCG, G, CG, ACG, ACG, ACG, AUA, CUAG $\}$ dan

G-fragments (disubfragmentasi dengan $(U, C)$-enzyme) $=\{\{G\},\{C-G\},\{C-U-U-C-C-G\},\{A G\},\{G\},\{A G\},\{G\},\{C-G\},\{A A G\},\{C-C-G\},\{G\},\{C-G\}$, $\{A C-G\},\{A C-G\},\{A C-G\},\{A U-A\},\{C-U-A G\}\}$

(U,C)-fragments (disubfragmentasi dengan $G$-enzyme) $=\{\{A G-G-C\},\{G-C\},\{U\},\{U\},\{C\},\{C\},\{G-A G-G-A G-G-C\},\{G-A A G-C\},\{C\},\{G-G-C\}$,

$\{G-A C\},\{G-A C\},\{G-A C\},\{G-A U\},\{A\},\{C\},\{U\}\}$

- Fragmen Abnormal $=\{\{\mathrm{AUA}\},\{\mathrm{A}\}\}$

- Unsplittable fragments $=\{\{\mathrm{G}\},\{\mathrm{AG}\},\{\mathrm{G}\},\{\mathrm{AG}\},\{\mathrm{G}\},\{\mathrm{AAG}\},\{\mathrm{G}\},\{\mathrm{U}\},\{\mathrm{U}\},\{\mathrm{C}\},\{\mathrm{C}\},\{\mathrm{C}\},\{\mathrm{A}\},\{\mathrm{C}\},\{\mathrm{U}\}\}$. Diketahui $\{\mathrm{C}\}$ merupakan awal rantai $R N A$ 
- Graf berarah :

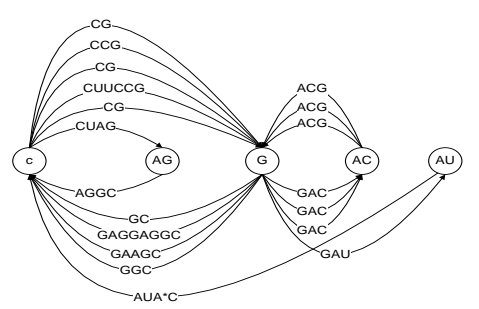

Gambar 22 : Graf Berarah RNA Ke-3 Organisme Human Herpesvirus 5

- $\quad$ Pencarian sirkuit Euler (algoritma van Aardenne-Ehrenfest dan de Bruijn) :

Spanning arborescence yang berakar di titik AG, yaitu :

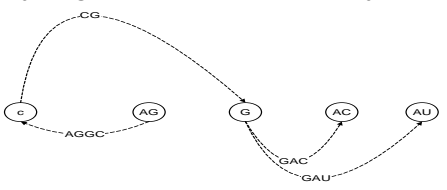

Gambar 23 : Spanning Arborescence untuk graf berarah RNA Gambar 22 Melabeli sisi-sisi berarah yang keluar dari titik-titik pada Gambar 22, yaitu :

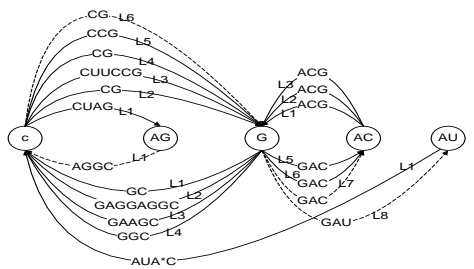

Gambar 24 : Pelabelan pada sisi berarah untuk graf berarah RNA Gambar 22 Mencari sirkuit Euler, yaitu dari Gambar 24 dapat dilihat sirkuit Euler yang terbentuk dengan memperhatikan tumpang tindih antar fragmen yaitu :

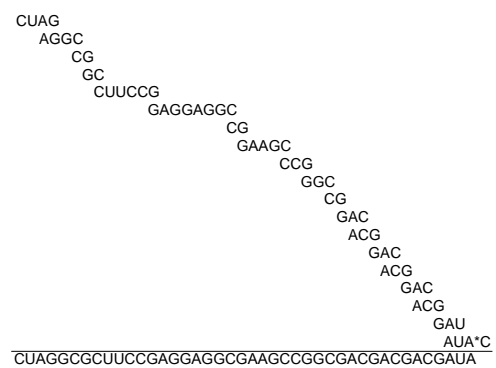

(3)

Gambar 25 : Hasil Rekonstuksi Rantai RNA Ke-3 Organisme Human Herpesvirus 5

Potongan rantai RNA ke-4 organisme Human Herpesvirus 5 yang akan direkonstruksi panjangnya adalah 30 yaitu "CUCCGCGUCACCUUUCAUCGAGUAAAACCU", sehingga

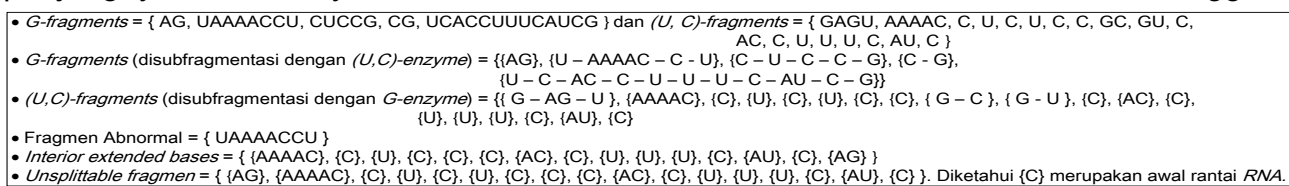


- Graf berarah :

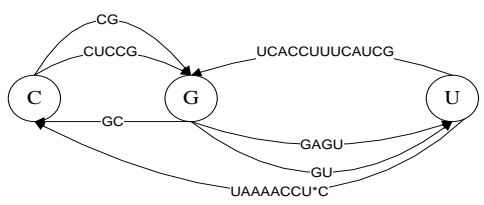

Gambar 26 : Graf Berarah RNA Ke-4 Organisme Human Herpesvirus 5

- Pencarian sirkuit Euler (algoritma van Aardenne-Ehrenfest dan de Bruijn) :

Spanning arborescence yang berakar di titik G, yaitu :

Gambar 27 : Spanning Arborescence untuk graf berarah RNA Gambar 26

Melabeli sisi-sisi berarah yang keluar dari titik-titik pada Gambar 26, yaitu :

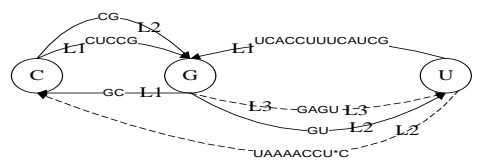

Gambar 28 : Pelabelan pada sisi berarah untuk graf berarah RNA Gambar 26

Mencari sirkuit Euler, yaitu dari Gambar 28 dapat dilihat sirkuit Euler yang terbentuk dengan memperhatikan tumpang tindih antar fragmen yaitu :

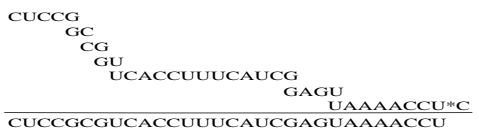

Gambar 29 : Hasil Rekonstuksi Rantai RNA Ke-4 Organisme Human Herpesvirus 5

Potongan rantai RNA ke-5 organisme Human Herpesvirus 5 yang akan direkonstruksi panjangnya adalah 24 yaitu "CUUUCUUUUCCGCGUGUCGGGUAG", sehingga

- G-fragments $=\{\mathrm{CG}, \mathrm{UG}, \mathrm{UCG}, \mathrm{G}, \mathrm{G}, \mathrm{UAG}, \mathrm{CUUUCUUUUCCG}\}$ dan $(U, C)$-fragments $=\{\mathrm{C}, \mathrm{GC}, \mathrm{GU}, \mathrm{GU}, \mathrm{C}, \mathrm{GGGU}, \mathrm{AG}, \mathrm{C}, \mathrm{U}, \mathrm{U}, \mathrm{U}, \mathrm{C}, \mathrm{U}, \mathrm{U}, \mathrm{U}, \mathrm{U}, \mathrm{C}\}$ - G-fragments (disubfragmentasi dengan $(U, C)$-enzyme) $=\{\{C-G\},\{U-G\},\{U-C-G\},\{G\},\{G\},\{U-A G\},\{C-U-U-U-C-U-U-U-U-C-C-G\}\}$ - (U,C)-fragments (disubfragmentasi dengan $G$-enzyme) $=\{\{C\},\{\mathrm{G}-\mathrm{C}\},\{\mathrm{G}-\mathrm{U}\},\{\mathrm{G}-\mathrm{U}\},\{\mathrm{C}\},\{\mathrm{G}-\mathrm{G}-\mathrm{G}-\mathrm{U}\},\{\mathrm{AG}\},\{\mathrm{C}\},\{\mathrm{U}\},\{\mathrm{U}\},\{\mathrm{U}\},\{\mathrm{C}\},\{\mathrm{U}\},\{\mathrm{U}\},\{\mathrm{U}\},\{\mathrm{U}\},\{\mathrm{C}\}\}$ - Fragmen Abnormal $=\{A G\}$

- Interior extended bases $=\{\{\mathrm{C}\},\{\mathrm{U}\},\{\mathrm{U}\},\{\mathrm{U}\},\{\mathrm{C}\},\{\mathrm{U}\},\{\mathrm{U}\},\{\mathrm{U}\},\{\mathrm{U}\},\{\mathrm{C}\},\{\mathrm{C}\},\{\mathrm{G}\},\{\mathrm{G}\}\}$

- Unsplittable fragmen $=\{\{\mathrm{G}\},\{\mathrm{G}\},\{\mathrm{C}\},\{\mathrm{C}\},\{\mathrm{AG}\},\{\mathrm{C}\},\{\mathrm{U}\},\{\mathrm{U}\},\{\mathrm{U}\},\{\mathrm{C}\},\{\mathrm{U}\},\{\mathrm{U}\},\{\mathrm{U}\},\{\mathrm{U}\},\{\mathrm{C}\}\}$. Dari Unsplittable fragmen diketahui $\{\mathrm{C}\}$ merupakan awal rantai $R N A$.

- Graf berarah :

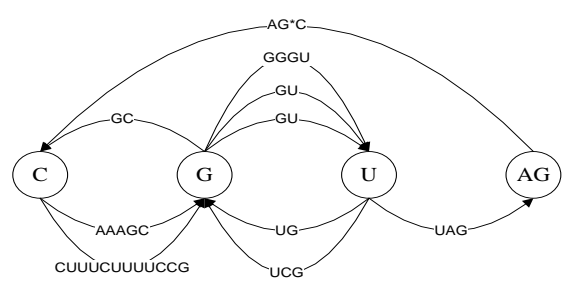

Gambar 30 : Graf Berarah RNA Ke-5 Organisme Human Herpesvirus 5

- Pencarian sirkuit Euler (algoritma van Aardenne-Ehrenfest dan de Bruijn) : 
Spanning arborescence yang berakar di titik $U$, yaitu :

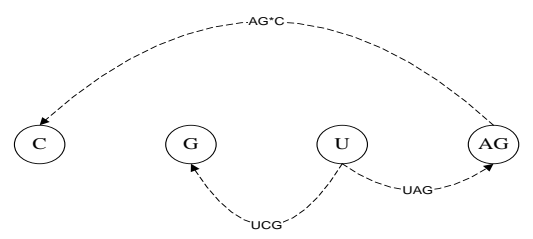

Gambar 31 : Spanning Arborescence untuk graf berarah RNA Gambar 30 Melabeli sisi-sisi berarah yang keluar dari titik-titik pada Gambar 30, yaitu :

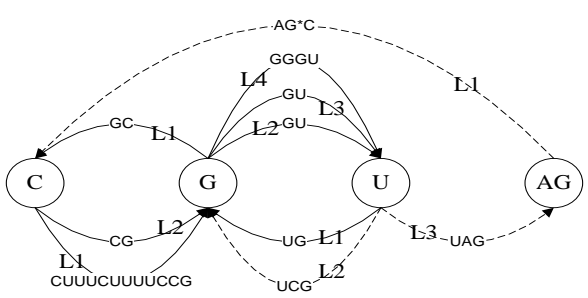

Gambar 32 : Pelabelan pada sisi berarah untuk graf berarah RNA Gambar 30 Mencari sirkuit Euler, yaitu dari Gambar 32 dapat dilihat sirkuit Euler yang terbentuk dengan memperhatikan tumpang tindih antar fragmen yaitu :

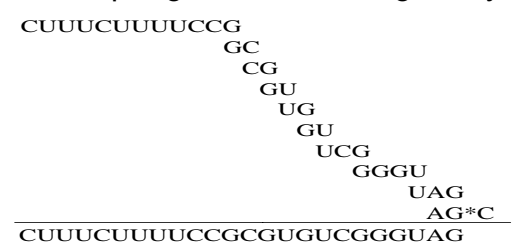

Gambar 33 : Hasil Rekonstuksi Rantai RNA Ke-5 Organisme Human Herpesvirus 5

Potongan rantai RNA ke-6 organisme Human Herpesvirus 5 yang akan direkonstruksi panjangnya adalah 27 yaitu "GGUACGGUUUAUUGCGACGGUCUUUCU", sehingga

- G-fragments = \{ ACG, G, UCUUUCU, G, G, UACG, G, UUUAUUG, CG $\}$ dan

(U, C)-fragments = \{ GAC, GGU, C, U, U, U, C, U, GGU, AC, GGU, U, U, AU, U, GC $\}$

- G-fragments (disubfragmentasi dengan $(U, C)$-enzyme) $=\{\{A C-G\},\{G\},\{U-C-U-U-U-C-U\},\{G\},\{G\},\{U-A C-G\},\{G\}$

- (U,C)-fragments (disubfragmentasi dengan $G$-enzyme) $=\{\{G-A C\},\{G-G-U\},\{C\},\{U\},\{U\},\{U\},\{C\},\{U\},\{G-G-U\},\{A C\}$

- Fragmen Abnormal $=\{$ UCUUUCU $\}$

- Interior extended bases $=\{\{C\},\{U\},\{U\},\{U\},\{C\},\{A C\},\{U\},\{U\},\{A U\},\{U\},\{G\},\{G\},\{G\}$

- Unsplittable fragmen $=\{\{\mathrm{G}\},\{\mathrm{G}\},\{\mathrm{G}\},\{\mathrm{G}\},\{\mathrm{C}\},\{\mathrm{U}\},\{\mathrm{U}\},\{\mathrm{U}\},\{\mathrm{C}\},\{\mathrm{U}\},\{\mathrm{AC}\},\{\mathrm{U}\},\{\mathrm{U}\},\{\mathrm{AU}\},\{\mathrm{U}\}\}$. Dari Unsplittable fragmen diketahui $\{\mathrm{G}\}$ merupakan awal rantai $R N A$.

- Graf berarah :

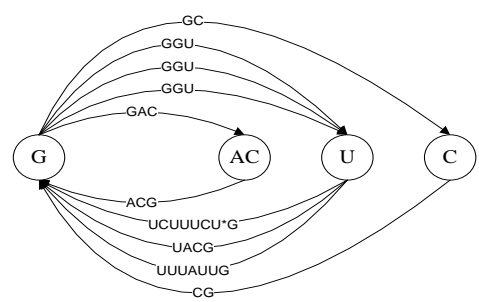

Gambar 34 : Graf Berarah RNA Ke-6 Organisme Human Herpesvirus 5

- $\quad$ Pencarian sirkuit Euler (algoritma van Aardenne-Ehrenfest dan de Bruijn) : 
Spanning arborescence yang berakar di titik C, yaitu :

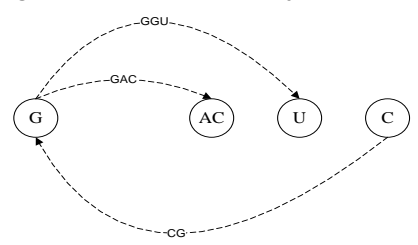

Gambar 35 : Spanning Arborescence untuk graf berarah RNA Gambar 34 Melabeli sisi-sisi berarah yang keluar dari titik-titik pada Gambar 34, yaitu :

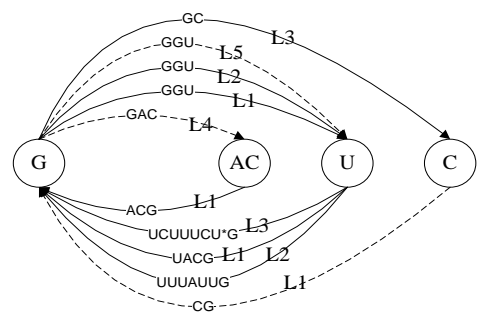

Gambar 36 : Pelabelan pada sisi berarah untuk graf berarah RNA Gambar 38 Mencari sirkuit Euler, yaitu dari Gambar 36 dapat dilihat sirkuit Euler yang terbentuk dengan memperhatikan tumpang tindih antar fragmen yaitu :

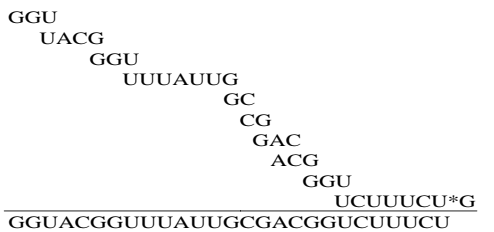

\section{(6)}

Gambar 37 : Hasil Rekonstuksi Rantai RNA Ke-6 Organisme Human Herpesvirus 5

Potongan rantai RNA ke-7 organisme Human Herpesvirus 5 yang akan direkonstruksi panjangnya adalah 21 yaitu "GAUUACGCGACCAGAUUGCAA", sehingga

- G-fragments = $\{$ AUUG, CAA, G, AUUACG, CG, ACCAG $\}$ dan $(U, C)$-fragments = $\{$ AGAU, U, GC, AA, GAU, U, AC, GC, GAC, C $\}$ - G-fragments (disubfragmentasi dengan $(U, C)$-enzyme) $=\{\{A U-U-G\},\{C-A A\},\{G\},\{A U-U-A C-G\},\{C-G\},\{A C-C-A G\}\}$ - $(U, C$ )-fragments (disubfragmentasi dengan $G$-enzyme) $=\{\{A G-A U\},\{U\},\{G-C\},\{A A\},\{G-A U\},\{U\},\{A C\},\{G-C\},\{G-A C\},\{C\}\}$ - Fragmen Abnormal $=\{\{\mathrm{CAA}\},\{\mathrm{AA}\}\}$

- Interior extended bases $=\{\{\mathrm{U}\},\{\mathrm{U}\},\{\mathrm{AC}\},\{\mathrm{C}\}\}$

- Unsplittable fragmen $=\{\{\mathrm{G}\},\{\mathrm{U}\},\{\mathrm{AA}\},\{\mathrm{U}\},\{\mathrm{AC}\},\{\mathrm{C}\}\}$. Dari Unsplittable fragmen diketahui $\{\mathrm{G}\}$ merupakan awal rantai $R N A$.

- Graf berarah :

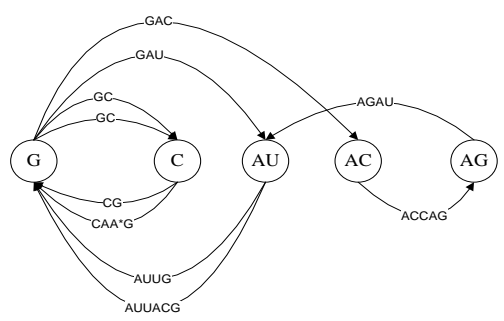

Gambar 38 : Graf Berarah RNA Ke-7 Organisme Human Herpesvirus 5

- $\quad$ Pencarian sirkuit Euler (algoritma van Aardenne-Ehrenfest dan de Bruijn) : 
Spanning arborescence yang berakar di titik AG, yaitu :

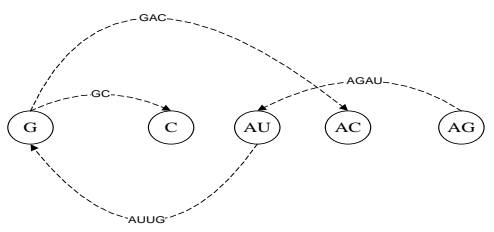

Gambar 39 : Spanning Arborescence untuk graf berarah RNA Gambar 38 Melabeli sisi-sisi berarah yang keluar dari titik-titik pada Gambar 38, yaitu :

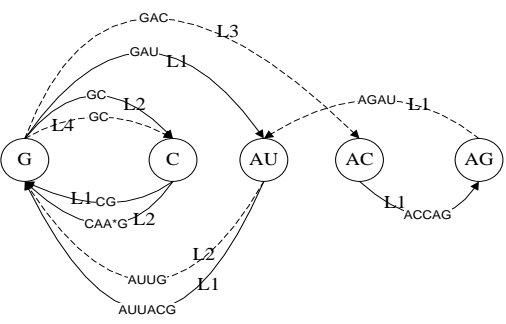

Gambar 40 : Pelabelan pada sisi berarah untuk graf berarah RNA Gambar 38 Mencari sirkuit Euler, yaitu dari Gambar 40 dapat dilihat sirkuit Euler yang terbentuk dengan memperhatikan tumpang tindih antar fragmen yaitu :

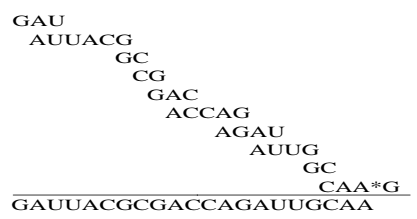

Gambar 41 : Hasil Rekonstuksi Rantai RNA Ke-7 Organisme Human Herpesvirus 5

Potongan rantai RNA ke-8 organisme Human Herpesvirus 5 yang akan direkonstruksi panjangnya adalah 30 yaitu "AAACCUACGUUGGUAGGUCACGUAGGUACG", sehingga

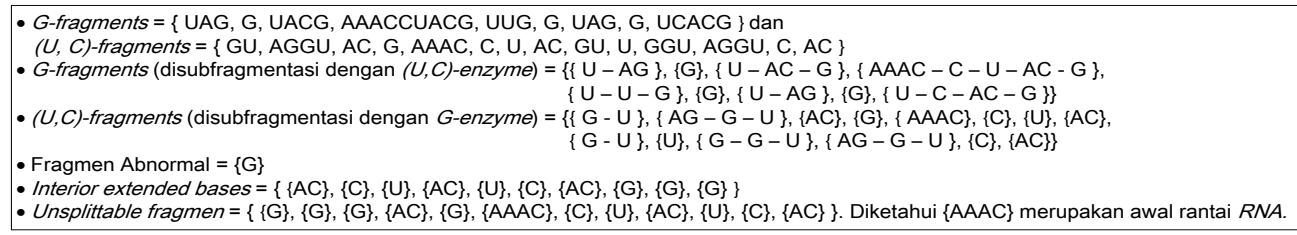

- Graf berarah :

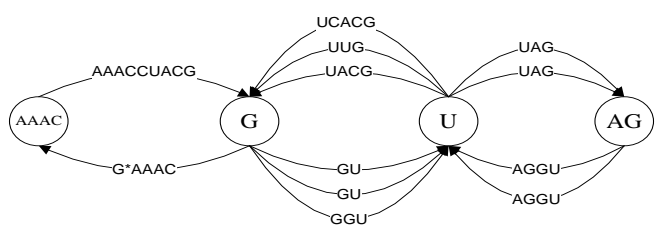

Gambar 42 : Graf Berarah RNA Ke-8 Organisme Human Herpesvirus 5

- Pencarian sirkuit Euler (algoritma van Aardenne-Ehrenfest dan de Bruijn) : 
Spanning arborescence yang berakar di titik AG, yaitu :

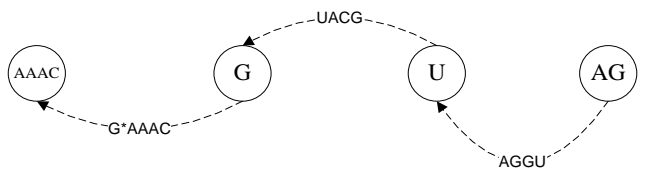

Gambar 43 : Spanning Arborescence untuk graf berarah RNA Gambar 42

Melabeli sisi-sisi berarah yang keluar dari titik-titik pada Gambar 42, yaitu :

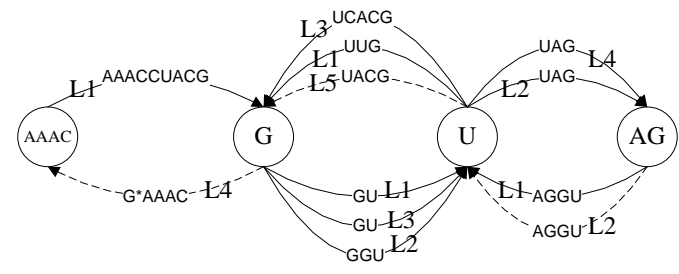

Gambar 44 : Pelabelan pada sisi berarah untuk graf berarah RNA Gambar 42 Mencari sirkuit Euler, yaitu dari Gambar 44 dapat dilihat sirkuit Euler yang terbentuk dengan memperhatikan tumpang tindih antar fragmen yaitu :

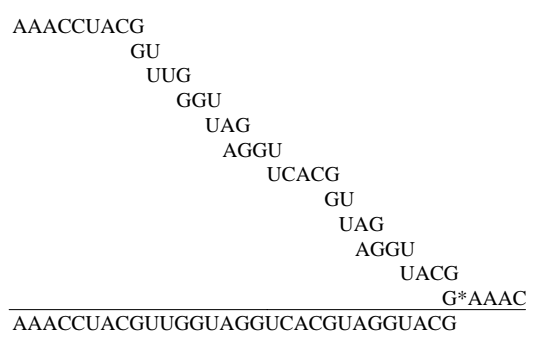

Gambar 45 : Hasil Rekonstuksi Rantai RNA Ke-8 Organisme Human Herpesvirus 5

Potongan rantai RNA ke-9 organisme Human Herpesvirus 5 yang akan direkonstruksi panjangnya adalah 15 yaitu "UUGCAAGAUCUCCGC", sehingga

- G-fragments $=\{$ AUCUCCG, C, UUG, CAAG $\}$ dan $(U, C)$-fragments $=\{$ AAGAU, C, U, C, C, GC, U, U, GC $\}$

- G-fragments (disubfragmentasi dengan $(U, C)$-enzyme) $=\{\{\mathrm{AU}-\mathrm{C}-\mathrm{U}-\mathrm{C}-\mathrm{C}-\mathrm{G}\},\{\mathrm{C}\},\{\mathrm{U}-\mathrm{U}-\mathrm{G}\},\{\mathrm{C}-\mathrm{AAG}\}\}$

- $(U, C)$-fragments (disubfragmentasi dengan $G$-enzyme) $=\{\{A A G-A U\},\{C\},\{U\},\{C\},\{C\},\{G-C\},\{U\},\{U\},\{G-C\}\}$

- Fragmen Abnormal $=\{\mathrm{C}\}$

- Interior extended bases $=\{\{\mathrm{C}\},\{\mathrm{U}\},\{\mathrm{C}\},\{\mathrm{C}\},\{\mathrm{U}\}\}$

- Unsplittable fragmen $=\{\{\mathrm{C}\},\{\mathrm{C}\},\{\mathrm{U}\},\{\mathrm{C}\},\{\mathrm{C}\},\{\mathrm{U}\},\{\mathrm{U}\}\}$. Diketahui $\{\mathrm{U}\}$ merupakan awal rantai $R N A$.

- Graf berarah :

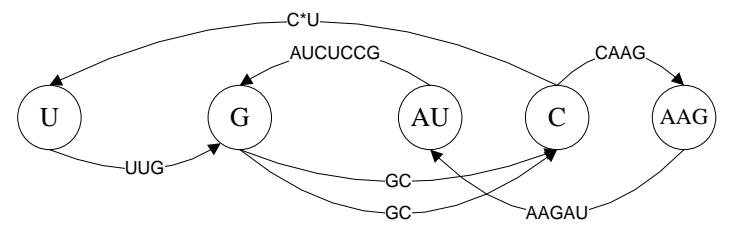

Gambar 46 : Graf Berarah RNA Ke-9 Organisme Human Herpesvirus 5

- Pencarian sirkuit Euler (algoritma van Aardenne-Ehrenfest dan de Bruijn) : 
Spanning arborescence yang berakar di titik C, yaitu :

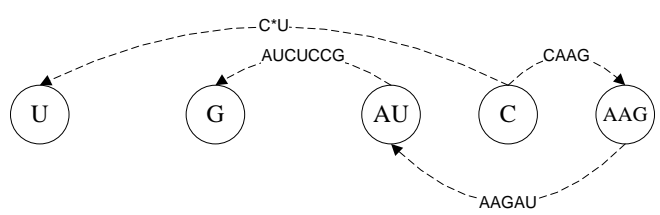

Gambar 47 : Spanning Arborescence untuk graf berarah RNA Gambar 46

Melabeli sisi-sisi berarah yang keluar dari titik-titik pada Gambar 46, yaitu :

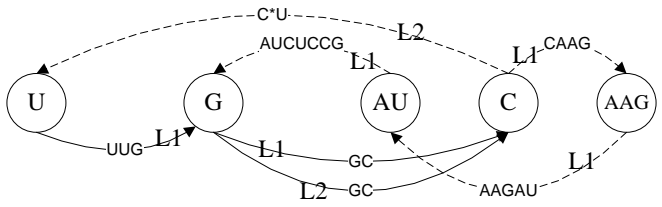

Gambar 48 : Pelabelan pada sisi berarah untuk graf berarah RNA Gambar 46 Mencari sirkuit Euler, yaitu dari Gambar 48 dapat dilihat sirkuit Euler yang terbentuk dengan memperhatikan tumpang tindih antar fragmen yaitu :

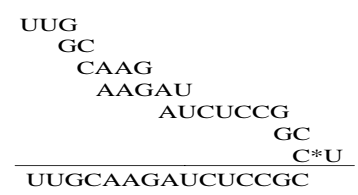

Gambar 49 : Hasil Rekonstuksi Rantai RNA Ke-9 Organisme Human Herpesvirus 5

Dari keseluruhan proses, diperoleh hasil rekonstruksi potongan-potongan rantai $R N A$ organisme Human Herpesvius 5 yang sama dengan rantai aslinya yaitu pada persamaan (1), (2), (3), (4), (5), (6), (7), (8), dan (9) dengan mencari sikuit Euler pada graf berarah RNAyang terbentuk menggunakan algoritma van Aardenne-Ehrenfest dan de Bruijn. Dari persamaan potongan-potongan rantai $R N A$ organisme Human Herpesvius 5 tersebut jika disatukan kembali menjadi rantai $R N A$ organisme Human Herpesvius 5 yang utuh akan menjadisebagai berikut:

\begin{tabular}{|c|c|}
\hline AUG CUG UCG GUG AUG GUC UCU UCC UCU CUG GUC CUG AUC GUC UUU CUU CUA GGC & (1) \\
\hline CUึA GGC GCU UCC GAG GAG GCG AAG CCG GCG ACG ACG ACG AUA & (3) \\
\hline ACG AUA AAG AAU ACA AAG CCG CAG UGU CGU CCA GAG GAU UAC GCG & (2) \\
\hline GÃU UAC GCG ACC AGA UUG CAA & (7) \\
\hline UƯG CAA GAU CUC CGC & (9) \\
\hline CUĈ CGC GUC ACC UUU CAU CGA GUA AAA CCU & (4) \\
\hline AÁA CCU ACG UUG GUA GGU CAC GUA GGU ACG & (8) \\
\hline GĞU ACG GUU UAU UGC GAC GGU CUU UCU & (6) \\
\hline CUŨ UCU UUU CCG CGU GUC GGG UAG & (5) \\
\hline $\begin{array}{l}\text { AUG CUG UCG GUG AUG GUC UCU UCC UCU CUG GUC CUG AUC GUC UUU CUU CUA GGC } \\
\text { UCC GAG GAG GCG AAG CCG GCG ACG ACG ACG AUA AAG AAU ACA AAG CCG CAG UGU } \\
\text { CCA GAG GAU UAC GCG ACC AGA UUG CAA GAU CUC CGC GUC ACC UUU CAU CGA GUA } \\
\text { CCU ACG UUG GUA GGU CAC GUA GGU ACG GUU UAU UGC GAC GGU CUU UCU UUU CCG } \\
\text { GUC GGG UAG }\end{array}$ & \\
\hline
\end{tabular}

Gambar 50 : Penyatuan Kembali Potongan-Potongan Rantai RNA Organisme Human Herpesvirus 5 Sehingga menjadi Rantai RNA Organisme Human Herpesvirus 5 yang Utuh. 


\subsection{Algoritma van Aardenne-Ehrenfest dan de Bruijn dalam Mencari Sirkuit Euler pada Graf Berarah untuk Merekonstruksi Rantai $R N A$ dari $G$-fragments dan $(U, C)$-fragments}

Berdasarkan Subbab 3.2. dan 3.3. maka merekonstruksi rantai $R N A$ dari G-fragments dan (U,C)-fragments menggunakan algoritma van Aardenne-Ehrenfest dan de Bruijn dalam mencari sirkuit Euler pada graf berarah sehingga mem peroleh urutan susunan barisan rantai $R N A$ yang sama dengan rantai $R N A$ asli, yaitu:

1. Mulai

2. Input panjang barisan rantai $R N A$ asli.

3. Input $G$-fragments dan $(U, C)$-fragments.

4. Subfragmentasikan $G$-fragments dan subfragmentasikan $(U, C)$-fragments, sehingga diperoleh extended bases.

5. Tentukkan Fragmen abnormal, pada tahap ini diperoleh fragmen yang merupakanakhir dari rantai $R N A$.

6. Dari extended bases, tentukkan interior extended bases.

7. Dari extended bases, tentukkan unsplittable fragments serta bandingkan dengan interior extended bases; pada tahap ini diperoleh fragmen yang merupakan awal dari rantai RNA.

8. Bangun graf berarah $R N A$.

9. Pencarian sirkuit Euler pada graf berarah $R N A$, yaitu :

- $\quad$ Bentuk spanning arborescence berakar disatu titik yang berkorespondensi dengan urutan susunan fragmen-fragmen rantai $R N A$ asli.

- $\quad$ Beri label pada sisi-sisi berarah yang keluar dari tiap titik-titik graf berarah $R N A$ yang berkorespondensi dengan urutan susunan fragmen-fragmen rantai $R N A$ asli.

- $\quad$ Cari sirkuit Euler dimulai dari titik dan sisi berarah yang merupakan fragmenawal rantai $R N A$ asli serta berakhir pada titik awal dan sisi berarah yang merupakan fragmen akhir atau fragmen abnormal sehingga hasil akhir sirkuit Euler memperoleh urutan susunan fragmen-fragmen rantai $R N A$ asli.

- Jika hasil akhir sirkuit Euler tidak memperoleh urutan susunan fragmen-fragmen rantai $R N A$ asli maka tahap pembentukkan spanning arborescence diulang kembali sampai memperoleh hasil akhir sirkuit Euler. Dan saat hasil akhir sirkuit Euler masih tidak memperoleh urutan susunan fragmen-fragmen rantai $R N A$ asli, maka antara urutan susunan fragmen-fragmen rantai $R N A$ asli dengan spanning arborescence yang dibentuk serta memberi label pada sisi-sisi berarah tidak saling berkorespondensi. Untuk itu maka panjang dari barisan rantai $R N A$ asli perlu dipotong kembali.

- Setelah memperoleh hasil akhir sirkuit Euler yaitu urutan susunan fragmenfragmen rantai $R N A$ asli maka selanjutnya dari fragmen-fragmen tersebut 
disatukan dengan memperhatikan tumpang tindih antar fragmen -fragmen yang bertetangga sehingga memperoleh urutan susunan rantai $R N A$ asli. Selesai.

\section{KESIMPULAN}

Berdasarkan hasil penelitian, dapat disimpulkan bahwa merekonstruksi rantai $R N A$ dari $G$ fragments dan (U,C)-fragments dengan menggunakan algoritma van Aardenne-Ehrenfest dan de Bruijn dalam mencari sirkuit Euler pada graf berarah dapat memperoleh urutan susunan barisanrantai $R N A$ yang sama dengan rantai $R N A$ asli.

\section{DAFTAR PUSTAKA}

[1] Agustina, Dwi dkk., Peranan RNA interference pada Embryonic Stem Cell, 2011, CDK, 186,38, No 5.

[2] Chartrand, G. Lesniak, L., Graphs \& Digraphs, Second Edition, Wadsworth \& Brooks/Cole, 1986, California.

[3] Eiselt, HA. Gendreau, M. Laporte, G., Arc routing problem, Part 1: The Chinese postman problem, 1995, Operat Res 43(2): 231-242.

[4] Gen Bank, NCBI (http:Ilwww.NCBI.com), Diakses: 19 September 2016.

[5] Noorzaman, G., Studi Implementasi Teori Graf dalam Rekonstruksi Rantai RNA dari Intisari Enzim Lengkapnya, ITB, 2007, Bandung. 